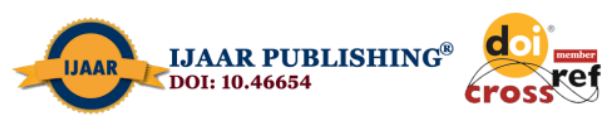

International Journal of Advanced Academic Research (Social and Management Sciences) | ISSN: 2488-9849 Vol. 6, Issue 6 (June, 2020) | www.ijaar.org

Journal DOI: 10.46654/ij.24889849

Article DOI: 10.46654/ij.24889849.s6626

\title{
ASSESSMENT OF NATIONAL SECURITY ISSUES IN DIFFERENT PARTS OF NIGERIA
}

\section{*Simon Stephen Mshelia, Arhyel Yususf Mbaya, Galkaye Emmanuel and Esther Solomon Kasuwa}

Department of Geography, Federal University, Gashua, Yobe State, Nigeria.

Email: msheliasimon48@gmail.com

Tel: +2348035755461

\begin{abstract}
The paper examined National Security issues in different parts of Nigeria: challenges to national development and unity. Data were obtained through primary and secondary sources that involved critical observations of events, incidences, views of different categories of people as well as authors in different places and works of life in the country on contemporary security issues. Government responses to the insecurity issues in the country were also studied. The study clearly reveals that Nigeria is presently facing serious internal security challenges from the Boko Haram/Islamic State of West African Province (ISWAP) insurgency; kidnapping; the Niger Delta militancy; cattle rustling, banditry and Fulani militia. Others are: ethno-religious conflicts, porous border and arms dealings and election-induced violence. The paper also identified poor governance, ineffective leadership and implementation of policies, poor transparency, accountability and disobedience to rule of law, weak government institutions and corruptions with impunity, unemployment, poverty, porous borders and affirmed that all these security challenges no doubt pose enormous threats to the social, economic and political stability of Nigeria. The paper is of the view that the key to finding national security in Nigeria is getting the right leadership and good governance to eradicate corruption, bridge multi-ethnic composition of the Nigerian society, holistically deal with the identified insecurity in the land and finding government that would give assurance and confidence to every citizen that his or her fundamental rights as stated in the constitution is guaranteed and protected.
\end{abstract}

Keywords: Banditry, good governance, insurgency, kidnapping, militia. 


\section{INTRODUCTION}

It is the desire and expectation of every individual or community to dwell in a geographical unit or location that is secured and devoid of danger or threat. The impracticable need for security in almost every facet of life has seen many people and even animals quest for peaceful and safe environment where lives and property are protected from threats or dangers. To be in such environment and for it to avail, it is absolutely imperative for an institution which is the Government to be in place; a machinery, or agency through which a political unit exercises authority and perform functions within the ambit of its power to play a significant role in the provision of peaceful and secured community to inhabit (Okonkwo et al., 2015).

It very disheartening to note that finding a secure place to live, especially in Nigeria today is difficult to come by. Unlike in the 1970s, when people had relative peace irrespective of religions, tribes and sex, had interacted freely with less or no harassment (Idoko and Dasuma, 2014).In those days, lives and property were secured because there was government that had her people at heart and took governance a point of duty. Military men were rarely seen on the roads or within the community as common as we see them today because there was relative peace. The fear of the military was then the beginning of knowledge but today the story is different because even dogs no longer bark at armed military men. The issue then, was people feared causing problems because of the wrath of the law or because there was good governance? There was good governance and as result the laws were dutifully obeyed. Security in the country was highly maintained unlike today where we have almost a lawless society where selective justice prevails (Okonkwo et al., 2015; Dambazzau, 2014).

Over the years, as far back as 1990s, the relative peace enjoyed by people deteriorated and what is called insecurity became very manifest. While security of lives and property of people residing in Nigeria were gradually eroding giving room to the insecurity, the Government gave little attention and overtime it fully crept into the fabrics of the nation. The inefficiency of response to the emerged insecurity by government had tremendously given birth to the many security challenges bedeviling the country today. The most serious ones being the Boko Haram insurgency in the northeastern states of Borno, Yobe, Adamawa, some parts of Northern Nigeria and in the fringes of Cameroon, Niger and Chad; and the Fulani Herdsmen Militia inthe North Central and Northwest; Niger Delta militancy and piracy in the south-south geopolitical zone, comprising Bayelsa, Delta and Rivers; Kidnapping, virtually in every part of the land but most pronounced in the North Central and North West and Central (Abuja, Kaduna, Lokoja) and River State among others, cattle rustling and banditry most common in the North West. Additionally, there are also security challenges posed by different kinds of violent crimes, ethnic or tribal and religious conflicts, trans-border criminal activities, election violence, conflicts as a result of resource locations, control and allocation and cybercrime. All these security challenges no doubt pose threats to the social, economic and political stability of Nigeria (Danbazzau, 2014). It is on these bases that the paper seeks to assess the national security, examine the various security challenges bedeviling the different parts of the country, impacts on the citizens and national unity as well as the ways forward.

\section{CONCEPTUAL CLARIFICATION}

The study gave the definitions of security and national security to further elucidate the concept of the security issues in different parts of Nigeria. 


\section{Security}

Security according to Nwagboso (2012) is the act of people being safe from danger or harm; it can also be viewed as the protections, defense, and preservation of values as well as the absence of threats to acquire values. Adejumo (2011) is also of the opinion that security is the act of maintaining or ensuring peace within governing territories by upholding the national law and defending the internal and external security threats in different parts of a nation. Similarly, Adebakin (2012) defines security as liberty from threats and dangers and the ability of a state or country to safe guard its citizens, values of the nation, develop itself, encourage legitimate interests and improve the well-being of its people. This freedom can be sustained through internal security system. Based on the above definitions of security therefore, insecurity can be deduced as when an individual, community or nation is faced with threat or danger. It can also be referred to as the state of being exposed to danger or threat from internal or external forces.

\section{National Security}

Bello (2017) argued that the term national security is very broad to give a precise definition but attempted it explanation as the concern of government about the stability and safety of a state that is being carried out using policies, strategies, military strength and whatever available within the context of law. More still, Ammerdown Group (2016) is of the opinion that national security deals with the security of a country or state which includes its citizens, economy, and institutions which is considered as the duty of government to meet. These definitions and descriptions have eroded the conception that national security as the military strength and its ability to defend the territorial boundaries against military attack. It encompasses all facets of security for social, economic, governance and political wellbeing of citizens and the entire nation. In this regards, it is pertinent for the government to play her cards very well in order to reduce all sorts of insecurity to the barest minimum (Nnoli 2006; Alozieuwa, 2012).

\section{METHODOLOGY}

\section{Study Area}

Location: Nigeria is located between latitude $4^{0} \mathrm{~N}$ and $14^{0} \mathrm{~N}$ of the Equator and between Longitude $3^{0} \mathrm{E}$ and $15^{\circ} \mathrm{E}$ of the Greenwich meridian. Furthermore, the latitudinal stretch of Nigeria is about $10^{\circ}$ while the longitudinal stretch is $12^{0}$. Nigeria is the largest black African Nation found in West Africa and covers a total area of $923,768 \mathrm{Km}^{2}$ with a projected population of $205,990,223$ (Worldmeter, 2020). The distance from east to west is approximately $1300 \mathrm{Km}$ while the distance from north to south is approximately $1,100 \mathrm{Km}$. It is bounded in the north by Niger Republic, the north-east by Chad Republic, in the east by Cameroun Republic, in the west by Benin Republic, and in the south by Atlantic Ocean (Olagunju, 2015). 


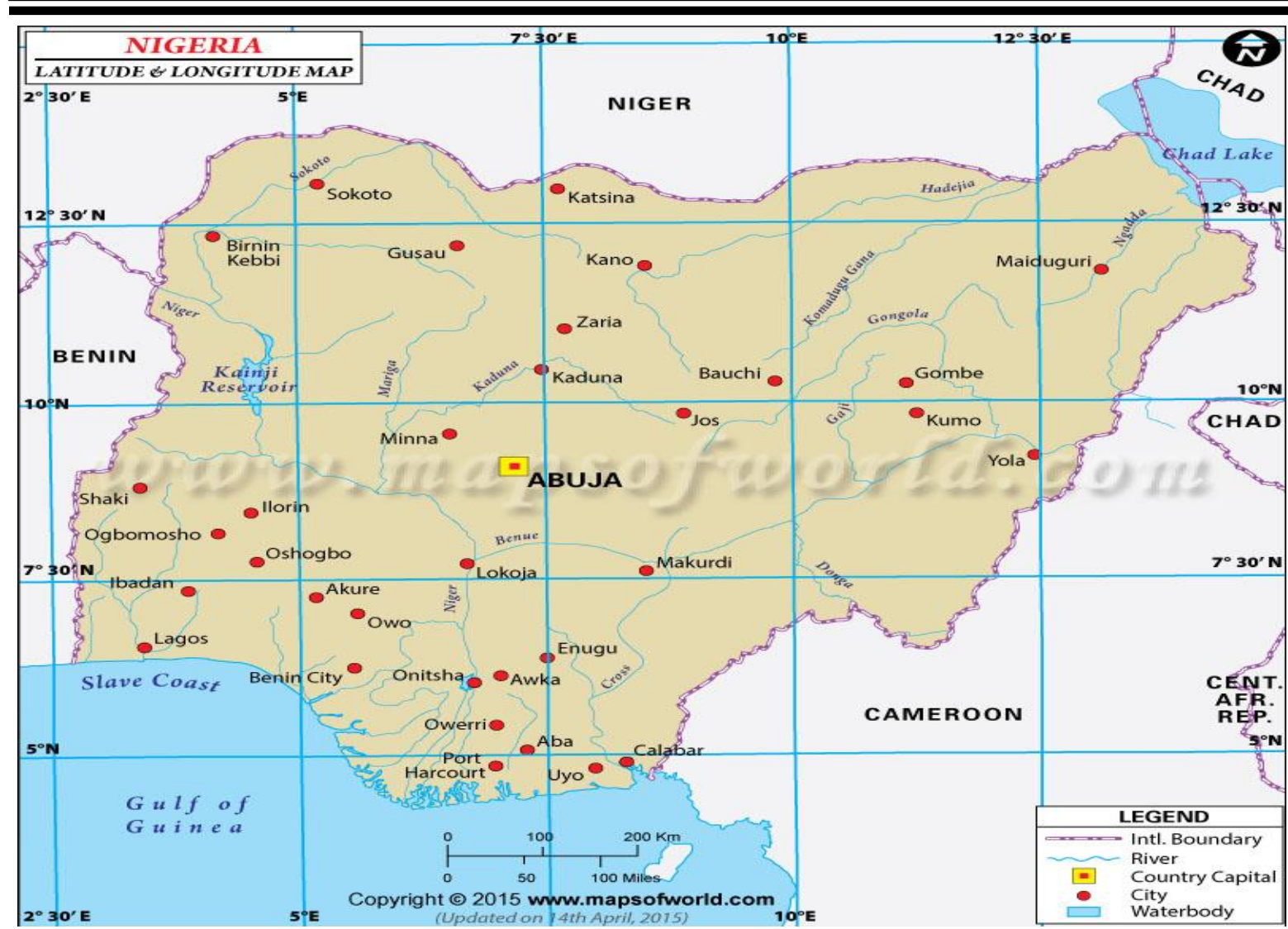

Figure 1.1: Map of Nigeria

Source: Adapted from Google Map

\section{Methods of Data Collection}

Primary data for the study were obtained through direct field visitations to some affected communities in Borno, Katsina, Zamfara, Yobe, Plateau and Kaduna States where some rural dwellers especially village heads were interviewed and the impacts of the Boko Haram/ISWAP insurgency, cattle rustling, banditry and kidnapping on the communities and the insecurity generated.Focus group discussion was also employed where data on Nigerian security issues were obtained. Data were also generated from review of relevant literatures, journals, conference papers, newspaper and the internet. Data obtained were analysed in a descriptive and narrative form.

\section{RESULT AND DISCUSSION}

\section{Contemporary National Security Issues in Nigeria}

It is no longer news that Nigeria is currently facing serious security challenges. Akanyadike (2013) is of the opinion that since the rebirth of democracy in 1999, the security situations in Nigeria have been very painful and disturbing. In the past 21 years, things have been getting worse almost every day. It is on this background that the Chief of Defence Staff, General Abayomi Olonisakin on $10^{\text {th }} \mathrm{July}, 2017$ revealed that the military was confronting 14 security threats across the country. Olonisakin disclosed this at a reception organised for him by the Permanent Mission of Nigeria to the United Nations in New York, the United States of America on the $10^{\text {th }}$ July, 2017.

Furthermore, Olanisakin (2018) stated that the most serious security threats in Nigeria are those in the category of discontent or separatist agenda, specifically the violent extremism of 
Boko Haram/ISWAP in the North East, the violent militancy in the Niger Delta, the Fulani Militia which are deadly and more prominent in the North Central, the Cattle rustlers and bandits in Zamfara, Sokoto, Katsina and Birnin Gwari in Kaduna State as well as the Kidnappers virtually all over the country but most pronounced in the in North Central especially along Kaduna - Abuja and Lokoja - Abuja Express Way, peri urban settlements in Abuja as well as Kaduna - Birnin Gwari Road.

\section{Insurgency/Terrorism}

Babangida (2012) is of the view that Nigeria along with Mali and Ethopia are some of the countries in Africa in which terrorism has emerged in form of terrorists and over time has taken the form of insurgency. Although, different groups have surfaced at different points in history of Nigeria in various forms, scope and the ways they operate, none is quite comparable with Boko Haram which is believed to be Abubakar Shekau group existing in the Sambisa forest, Mandara/Gwoza Mountains and some parts of Cameroon (Adagba et al., 2012). The other faction is the Islamic States of West Africa Province (ISWAP) aligning with Islamic State of Iraq and the Levant (ISIL) occupies the Lake Chad area and some fringes of Chad Republic. The insurgents occupy the North East and some are scattered in the northern parts of Nigeria as informants, sympathizers and suppliers. The Boko Haram as well as the ISWAP has carried several attacks, killing in different forms, kidnapping, abductions (the Chibok in Borno and the Dapchi in Yobe secondary school girls) and lootings on both soft and high profile targets in northern parts of Nigeria including the Federal Capital Abuja.

The present government repeatedly said that Boko Haram has been decimated in the Northeast but available evidences and recent attacks especially on military formations, facilities and killings of people clearly showed that they are still very strong and active. Sahara Reporters of $15^{\text {th }}$ October, 2019 reported that a Senator representing Borno South and also the Chairman Senate committee on Army said that 840 Nigerian military men were killed by Boko Haram terrorists from 2013 to October, 2019 excluding the soldiers killed and buried in other cemeteries and the military cemetery Maiduguri, Borno State. Aljezeera news Cable reported that BH/ISWAP on 20/03/2020 killed 12 Soldiers, 24/03/2020 50 Soldiers were at least killed and on 10/06/2020 no fewer than 81 people were killed by Boko Haram/ISWAP in Felo village Gubio LGA. Similarly, on 14/06/2020 BH/ISWAP killed 20 soldiers and 40 civilians in Monguno and Nganzai areas of Borno State. The daily attacks and killings are countless. Government has invested so much to ensure that the insecurity cause of the $\mathrm{BH}$ sect is curtailed but there is still very much that have to be done, thousand miles must be covered to actually tackle the menace in the area.

\section{Crude Oil Theft and Bunkering}

Insecurity such as the crude oil theft and bunkering avail greatly in the Niger Delta region which is considered as the treasure trove of Nigeria. These actions perhaps of the militants and men of the underworld, no doubt are capable of causing major security concern to the well-being of the country. The acts include crude oil theft, illegal refining, piracy and kidnapping of mostly expatriates (Okonkwo et al., 2015). More still, the massive environmental degradation through oil spillages and flaring of gas, poor mop-up and discharge of chemicals (heavy metals) in the environment without recourse. Government and foreign multinational industries/companies neglects to clean up and also to see to some basic needs of the residents has continued to generate tension in the area constitute threats and dangers as well as health security. Although, government (the late Yar'Adua administration) 
had done well in mitigating militancy in the region but the national responses to these threats need to be further intensified (Ogbonnaya and Ehigiamusoe, 2013).

\section{Communal, Ethno-Religious Conflicts and Poor Politics}

Sule (2015) is of the view that one of the major problems militating against the socioeconomic and political development of Nigeria has been the recurrent and frequent incidences of communal and ethno-religious crises and the attendant destructive effects in many parts of the country especially in the North. Religious crises are constantly reoccurring incidences in northern Nigeria especially in Kaduna, Kano, Plateau, Bauchi and Katsina States among others. Similarly, ethnic conflicts between Hausa communities and indigenes of Oyo and Lagos States, the Jukun-Tiv in Taraba and Benue; have mostly been violent and continued to escalate in virtually all the geo-political zones of the country (Agaptus, 2012). Tokunbo and Oladipupa (2017) are of the opinion that ethno-religious conflicts have polarized the country towards sentiments and nepotisms and if unchecked it would compromise the corporate existence of the Nigeria. This is because the communal and ethnoreligious conflicts have raised dusts of land ownership, citizenship and gender right, and right to live in any part of the nation which to date are yet to be adequately addressed. Such outbursts of violence will continue to create a politically-apprehensive environment and consequent insecurity (Boemeken and Schetter, 2017).

Nweke and Stephen (2018) opined that partisan politics in Nigeria over the decades has been characterized by electoral violence, fraud and manipulation which often results to crises and those affected often take the law into their hands. There has never been election without violence and deaths in the past twenty years Nigeria.

\section{Kidnapping}

Kidnapping is arguably one of the newest and latest threats. It is partly attributed to the growing unemployment syndrome in the polity and bad governance (Pius, 2018). Owing to its relative ease compared to robbery, poor intelligence, incapability of the Police to track the locations of phone calls and the kidnappers and the manner at which it is designed and executed as well as the huge and quick proceed on crime have made kidnapping the most attractive and arguably the fastest means of getting money. In Nigeria today, kidnapping has grown into multi-billion Naira business which posed grave threat to personal, social and economic security. No wonder, even families now kidnap one another. We have heard cases of children, gatemen and neighbours collaborated and kidnapped their parents, boss and friends in order to get money out of them. An interview with Yakubu Dogo of Mararaban Rido of Kaduna metropolis who was kidnapped along Abuja - Kaduna road on $23^{\text {rd }}$ November, 2018 reveals that the abductors were Fulanis, On $28^{\text {th }}$ September, 2015 in an interview with the Nation News Paper Olu Falae, an elder state man, a banker, one time Secretary to the Federal Government and a Presidential aspirant reported that he was kidnapped and tortured by Fulanis. The activities of the Fulanis in Nigeria are national threats and if it continues to go unchecked it will no doubt one day spill the powder out of the keg and the resultant effects would be unimaginable. Many kidnapping cases have occurred in Nigeria over the years especially, between 2016 and 2020 as shown on Figure 2.4.1. 


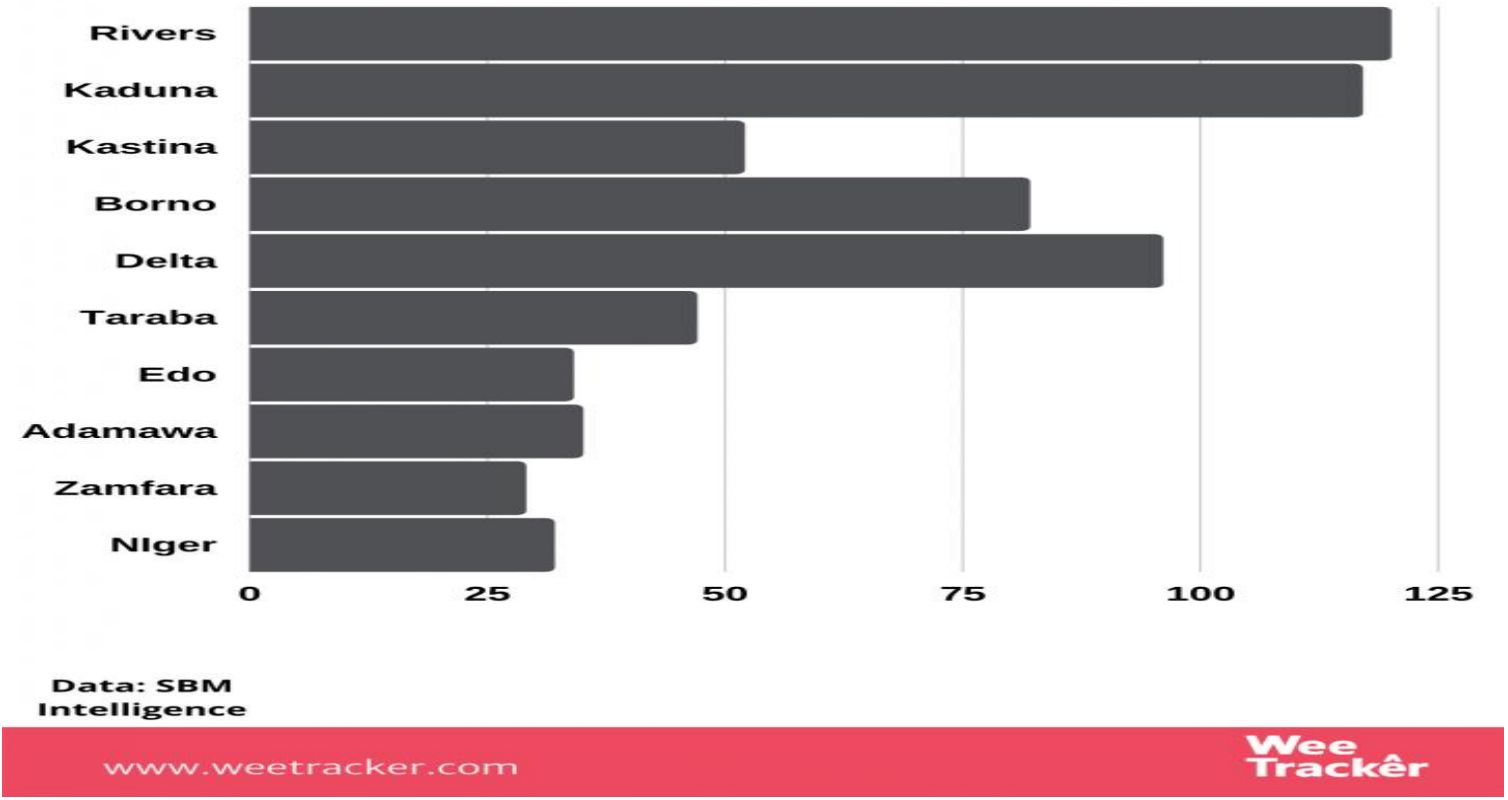

Source: Adopted from Andrew Christian (2020)

Kidnapping incidents are generally underreported in Nigeria. Many people do not trust the police for fear that contacting security services will put their loved ones at greater risk. This results in inadequacy of reliable official crime data in the country. According to the United Nations Office on Drugs and Crime (2017), using data from law enforcement agencies of member states, 277 kidnappings were reported in Nigeria in 2007; 309 in 2008; 703 in 2009; 738 in 2010; 600 in 2012; and 574 in 2013. No data were provided for 2011. In 2015, the Nigeria Police Force reported 886 kidnappings occurred. About 630 people were reportedly abducted between May 2016 and May2017. In May 2018, gunmen reportedly kidnapped 87 passengers from several vehicles along the Birnin Gwari-Kaduna highway in Kaduna state, north-central Nigeria and in the first quarter of 2019 police reported that 685 kidnapping occurred nationwide (The Daily Trust Newspaper of $23^{\text {rd }}$ July, 2019)

\section{Fulani Herdsmen Militia}

According to Olaniyan and Yahaya (2016), the Fulani are mostly concentrated in the north but perhaps as a result of political instability and drought they move further down south in search of pasture for their animals. In the course of the movement they likely eat up crops or plants of the local communities which always result into conflict. Over the past few years, tensions and violence between farmers and herdsmen have risen sharply and intensified in 2018 where the herdsmen in a brutal and barbaric ways; killing males and females as well as children without recourse as were in the cases of Agatu in Benue state, Sanga in Kaduna State and some communities in Taraba and Plateau states and further exacerbated the security issues in Nigeria. According to Pius (2018) that about 1,600 people were killed and another 300,000 displaced due to the violence and the heinous activities of the herdsmen better identified as the Fulani Militias. The attacks by herdsmen in many cases have become the most potent threat to national security in the last previous present years (Pius, 2018). They also burnt down the houses, food barns or silo of the communities attacked which most often 
displaced the ones that survived the attacks. It is on the basis of this that Olainyan and Yahaya (2016) and Pius (2018) reported that the country never experienced the level of destruction and social dislocation as we have today.

National Daily Newspaper of $1^{\text {st }}$ May, 2020 and $25^{\text {th }}$ May, 2020 reported that Fulani herdsmen killed several people at Itakpa, Obi LGA of Benue State and slaughtered 16 children and women at Tudun Doka in Kachia LGA of Southern respectively. Similarly, on $28^{\text {th }}$ May, 2020 the Opera news reported that the Adara Development Association in Kaduna said that no fewer than 107 people killed, 111 houses burnt, 32 villages destroyed and about 20,000 displaced from January to May, 2020 by the Fulani militia. The disturbing issue with these kinds of attacks is how they are in almost all cases happened under the eyes of security. These activities of herdsmen no doubt pose more threats than any other security challenge in the country at the moment (Olaniyan and Yahaya, 2016).

\section{Cattle Rustling/Banditry}

Cattle rustlings and banditry have recently become a major internal security concern in Nigeria, especially in North Central and North West. The bandits with automatic weapons use to storm herders' settlements and pillage cows. In most cases, the rustlers kill and maim their herders and rape the women before carting away their cows (Akowe and Kayode 2014). In some instances, they also kidnap girls or women in the process. Virtually, all of the states in the northern region of Nigeria are affected by cattle rustling. In Plateau State, cattlerustling activities are prevalent in eight (Mangu, Bokkos, Barkin Ladi, Shendam, Jos South, Riyom, Langtang North, and Langtang South) out of the 17 local government areas (Azinge, 2013). From 2011 to 2017 about 15,000 cattle were rustled by the suspected armed bandits and the owners are left to survive in a state of uncertainty (Shehu et al., 2017). Similarly, His Excellency, Hon. Aminu Bello Masari, the governor of Katsina State, announced the recovery of 30,000 cattle from rustlers within a few months of setting up a joint military operation against the menace in 2016 (Tauna 2016). Today, the bandits and rustlers are back and having field day in Katsina State. On 27/05/2020 Daily Trust News reported that bandits killed 74 people in Sabon Birni, Sokoto State. Many of the atrocities of the bandits and militia have been under reported and they have continued to unleash harm and injuries on the rural dwellers in different parts of the country.

\section{Government Failure and Prevalent Inequality}

Igbuzor (2011) is of the opinion that the Nigerian foundations of institutional framework are very weak, shaky and porous. These have resulted to poor governance and accountability which by and large crumbled structures in the government institutions because rules are not being obeyed or followed and only the well placed in the society are attended to. Igbuzor (2011) further observed that it is not out of place to say that the state of insecurity in Nigeria is tremendously a function of government failure. This is a clear fact as a result of the incapacity of government to manage public utility services and to provide for basic needs of the citizens. The country experience epileptic power supply, no pipe borne water, dilapidated school structures or building without furniture, bad roads, and ill equipped hospitals among others. Furthermore, money vouched for projects are not truly utilized but ends off in individual pockets which has made people frustrated, vulnerable and could easily become any event violent at any slight issue.

Hazen and Horner (2007) described the Nigerian situation as a 'Paradox of Plenty'. This defines a situation where the country generate sufficient income through sales of mineral resources such as oil, but fails to use the revenue judiciously to provide the basic needs of its 
people, develop infrastructures and grow the economy. Under such condition where a country has abundance but fails to deliver then, crime rate is bound to rise and the security of lives and property cannot be guaranteed.

Dambazzau (2014) argued that bad governance in Nigeria has resulted to disparities, inequality and unfairness in the distribution, allocation and appointment of resources, infrastructure and political positions respectively. These have tremendously stemmed the perception of marginalization by some geographical zone or section of people. Large numbers of the Nigerians are frustrated and their hope is shattered, especially the youths. Many of the Nigerian population today, have been expressing their disillusion about the pervasive state of inequality in the country as a result of government failures through the favoritism of certain religion or tribe and nepotism. Qualification, competency and capability have been negated and this continues to brawl and may explode at certain point in time to cause wanton havoc.

\section{Weak Security System and Porous Border}

The security system in Nigeria is generally weak. It is characterized by inadequate equipment or gadgets for the security arm of government, both in terms of weaponry and training; poor behavioural and attitudinal disposition of security personnel and poor intelligence. Many activities of the bandits, kidnappers and other form of crimes often use to take place a stoned throw from the security personnel duty post with impunity (Shehu et al., 2017). Their response to distress calls in very poor and many of them do not have the expertise and integrity to perform. Thus, instead of being the national watch dogs and be there for the civilian from being harmed by criminals, many of them are saboteurs of government effort, support and fuel insecurity through conniving with the criminal or lackadaisical habit (Nweke and Stephen, 2018).

The weak security system has also to a large extent contributed to the porous borders which has enhanced insecurity in Nigeria, where individual and group movements are largely unchecked and untracked. The porosity of Nigeria's borders has become the gate of ease movement of Small Arms and Light Weapons in to the country which has aided BK, militant groups and criminal groups to have easy access to arms (Hazen and Horner, 2007). Nigeria is estimated to host over 70 percent of about 8 million illegal weapons in West Africa (Edeko, 2011). Today it is on record that there are over 10 million illegal weapons in Nigeria (Olanisaken, 2017). Also, the porosity of the Nigerian borders has made it possible for unwarranted influx of migrants from neighbouring countries such as Republic of Niger, Chad and Republic of Benin (Olanisakin, 2017). These migrants which are mostly young men and some could be perpetrators of the crimes in the country.

\section{Unemployment, Poverty and Corruption}

The high levels of unemployment and poverty among Nigerians, especially the youths, have a great tendency of them being attracted to violent crime (Adagba, et al., 2012). According to NBC (2019) the unemployment rate among youths keeps increasing as indicated by the statistic where in 2007 the rate was $8.5 \%$; 2010 it was $9.7 \%$; 2015 was $16.3 \%$ and it was $20 \%$ in 2019 Piecher (2020). Nwagbosa (2012) argued that the failure of successive government in Nigeria to tackle challenges of poverty, unemployment and inequitable distribution of wealth among ethnic groups is one of the major causes of insecurity in Nigeria. More still, the multidimensional poverty index reported in 2017 that $54.1 \%$ of Nigeria's population live in poverty and this placed Nigeria as a troubled country (Nweke and Stephen, 2018). 
Unemployment can also attribute to poverty and corruption. No doubt, it is no longer news that Nigeria has consistently occupied a space among the most corrupt nations in the world as rated in the Corruption Perception Index of the Transparency International (TI). On a 0-100 scale (highly corrupt to very clean), where Nigeria scored 25\% and ranked 144 out of 177 assessed nations in the world (TI Ranking, 2013), The country ranked 144 out of 180 in 2018 and in 2019 Nigeria ranked $4^{\text {th }}$ most corrupt in the world (Nweke and Stephen, 2018).

\section{CONCLUSION, PRAYERS AND WAY FORWARD}

Dambazzau (2014) is of the view that the security situations in Nigeria can be related to the analogy of the breeding of mosquitoes. Ordinarily, mosquitoes hardly breed in clean habitats where there is no stagnant water but breed very well in dirty environment where there are enough stagnant and contaminated water. The larvae survives better in shallow or stagnant water as well as in where streams dry up living behind stagnant puddles in the stream bed (Virginia Department of Health); Like the mosquitoes, insecurity flourishes more in corrupt and poorly governed country having weak government. Insecurity in the country knows no bound ranging from the Boko Haram/ISWAP insurgency and its killing of both civilians and military in the northeast; the cattle rustlers and banditry which have killed hundreds of people and displaced thousands; militancy in the Niger Delta; the kidnappings and rape which have sent shivers into the nerves of citizens; Fulani herdsmen militia who are very brutal and deadly; violent crimes of armed robbery; arms smuggling across the porous border; the violence resulting from elections; the ethno-religious conflicts resulting in violent destruction of lives and property; the deaths as a result of road traffic from poor roads negligence and poor enforcement; pandemic diseases such as the COVID-19, malaria and HIV/AIDS; the environmental threats of anthropogenic activities of man. The list of insecurity in Nigeria is endless.

The study identified that the key to finding the security challenges in Nigeria depends on finding the appropriate leadership that would bring to fore better leadership and good governance: that would nip corruption to the bud as well as leaders that would make transparency and accountability their pillars. To arrest the insecurity issues in the country there is absolute need for leaders that would be fair and just to the citizens irrespective of class, status, religion, ethnicity, sex and tribe. Leaders that would uphold the constitution of the Federal Republic of Nigeria recognizing the multi-religious and multi-ethnic composition of the Nigerian society and make them realize that there is unity even in cultural diversity; that would support and strengthen the key institutions of governance, such as the judiciary, the security agencies, educational and health sectors among others. The study is referring to leaders that would give a shining face to the socio-economic well-being of Nigerians and make them self-reliant; that would revitalize Nigeria's foreign policy focus and boost the economy of the country; that would emphasize unity even in cultural diversity to ensure stability; a leader that would recreate, redesign the security to find solutions to the current insecurity issues bedeviling the country among others. Similarly, the citizens are also expected to be law abiding and have love of the country at heart. These steps would no doubt pave ways for new Nigeria.

Having studied the security issues in Nigeria, it is not out of place to opine that the factors are indeed facilitators and indicators of the contemporary Nigeria's security issues. The poor leadership, weak security system, inequality, nepotisms, poverty, unemployment, political instability, unfairness, lopsided appointments and corruptions have greatly triggered the insurgency, terrorism, banditry, kidnapping, militancy and perhaps other criminal activities in 
the country which place Nigeria on keg of gun powder ready to blow unless deliberate effort is made to address the security issues in the country.

From all indications, national security issues are big challenges in Nigeria's effort to develop as a united nation. The primary responsibility of any government is to ensure the security of lives and property of the citizens. Thus, it is imperative to consider the following:

a. Government should decentralized power to give the federating units power to attend to urgent security matters. This is because the federal system of government has been polluted and adulterated by power mongers.

b. The judiciary system in the country needs to be restructured and strengthened by giving it autonomy to ensure free and timely dispense of justice without being influenced. Anybody who commits an offense irrespective of religion, sex or status in the society should be prosecuted according to the law.

c. The rule of Nigeria as an egalitarian society instead of having two set of rules; one meant for the rich and the other for the poor.

d. Political praise singers and political scavengers must be banned in the patterns of our politics to accord the political office holders the right atmosphere to serve the general public instead individual aggrandizement.

e. Concerted and deliberate efforts should be made toward eliminating corruption and other corrupt practices in the country. Accountability should be the watch word of the government under the holistic command and control of the Economic and Financial Crime commission (EFCC) and Independent Corrupt Practices Commission (ICPC). They should be made autonomous and be devoid of interference or intervention by any highly placed office holders, money bags and god fathers in the country or beyond. The political institution in Nigeria needs to be strengthened, encouraged and overhauled. The issue of rigging election to come into power must be stopped instead, the election system should be geared towards making sure that fair and free elections are always conducted and not just preached.

f. Employment which is only in the hands of the legislators and other political office holders should seriously be addressed to give room for merit. The private sectors should be encouraged and supported by government by providing power and other infrastructures to create job opportunities to the teeming population especially the restive youths in the country.

g. Government should ensure constant power supply (electricity) and provision basic utilities which in turn encourages and influences employment opportunities and increase productivity.

h. There is the need for collective and joint security arrangements such as the Joint Task Force (JTF) by the three arms of government to ensure adequate provision of intelligence and other sensitive security information. The committee should cut across all levels from the federal to wards in the Local Government Areas. This will tremendously help in knowing the men of the underworld, their sponsors and hideouts in the country.

i. Federal and State Governments should decisively identify and address the remote causes of insecurity in Nigeria.

j. More importantly, Our Military, Police and other security agencies must to be well-equipped, trained, re-trained and develop positive attitude to tackle present day security challenges. They must be proactive rather than the practice of damage control they often engage in. To overcome insecurity there is need for 
intelligence gathering and surveillance so that law enforcement agents could be proactive and reasonably predict potential crime with near perfect accuracy rather than being reactive. Civilians and locals can be used for intelligence gathering. Good and sophisticated technology driven weapon should be provided to march the fire power of the criminals. 


\section{REFERENCE}

Adagba, .O, Ugwu, .S. C. and Eme, .O.I (2012), Activities of Boko Haram and Insecurity Problems in Nigeria. Arabian Journal of Business and Management Review. Vol. 1(9):145 -155.

Adebakin, M. A. (2012). National Security Challenges and Sustainable Economic Development: Evidence from Nigeria. Journal of Studies in Social Sciences 1(1):1-30

Adejumo A. (2011) . The Problems and Challenges of Insecurity in Nigeria. Culled from http://chatafrik.com/articles/nigerian- affairs/

Agaptus, N. (2013). National Security, Religious Anarchism and the Politics of Amnesty in Nigeria. Covenant Journal of Politics and International Affairs. Vol. 1(1) (Maiden Edition), Retrieved September 18, 2013.

Akowe, T, and Kayode, B. (2014). Cattle Rustling: A Northern Nigeria Nightmare, in the Nation $30^{\text {th }}$ March, 2014, on line www.nationoonlineng.net.

Aljezeera Cable News (2020). Documentary on Terrorisms and Insurgency in Africa from $1^{\text {st }}$ January to May, 2020. www.aljezeeranews.com

Alozieuwa, S.H.O. (2012). Contending Theories on Nigeria's Security Challenge in the Era of Boko Haram Insurgency. The Peace and Conflict Review. 7(1),16-22.

Ammerdown Group (2016). Rethinking Security, A Discussion Paper. http://creativecommons.org/licenses/by-nc/4.0

Andrew, C. (2020). Kidnapping is a Threat to Nigeria Business: It is a Worry for the Poor. www.tracker.com

Anyadike, N. O. (2013). Boko Haram and National Security Challenges in Nigeria; Causes and Solutions. Journal of Economics and Sustainable Development 4(5), Retrieved from: http://www.iiste.org.

Azinge, E. (2013) Military in Intern al Security Operations: Challenges and Prospects. A paper presented at the Nigerian Bar Association 53rd Annual General Conference on the 28th of August 2013. Tinapa Calable

Babangida, M. A. (2012). The search for National Security in Nigeria; Challenges and Prospects. A Paper Presentation at Obafemi Awolowo Institute of Government and Public Policy, Agip Recital Hall, Muson-Lagos; Thursday, 27th September, 2012.

Bello, F. (2017). Public Policy Implication on National Security; Org/journal/Fatima.bellolaw. 56

Boemeken, M. and Schetter, C. (2017). Security: What is it? What Does it Do? http://wwwlibrary.fees.de/pdf-files/

Dambazzau, A. (2014). Nigeria and Her Security Challenges. A Paper presented at InterAgencies Capacity Building workshop at Federal civil Servant Collge, Kubwa, Abuja on $13^{\text {th }}$ June, 2014. 
Edeko S. E. (2011).The Proliferation of Small Arms and Light Weapons in Africa: A Case Study of the Niger Delta in Nigeria, Sacha Journal of Environmental Studies, Volume $1: 2$, pp. $55-80$.

Hazen, J.M. and Horner, J (2007). Small Arms, Armed Violence, and Insecurity in Nigeria: The Niger Delta in Perspective, Switzerland: Small Arms Survey.

Idoko , C. U and Dasuma, A. M. (2014). Security Challenges in Nigeria and National Transformation, International Journal of Managerial Studies and Research, Vol. 2, (8):8-16.

Igbuzor, O. (2011). Peace and Security Education: A Critical Factor for Sustainable Peace and National Development, International Journal of Peace and Development Studies Vol. 2(1), 1-7, January.

National Daily Newspaper of $1^{\text {st }}$ May, 2020 and $25^{\text {th }}$ May, 2020.

Nweke P. and Stephen T.N. (2018). National security issues and challenges in Nigeria: Which way forward; International Journal of Youth Empowerment and Entrepreneurship Development. Vol. 1(1), 96-106.

Nwagboso, C. I. (2012). Security Challenges and the Economy of the Nigerian State (2002 2011), American Journal of Contemporary Research, Vol. 2(6): 244-256

Ogbonnaya, U.M. and Ehigiamusoe, U.K. (2013) Niger Delta Militancy and Boko Haram Insurgency: National Security in Nigeria. Global Security Studies, Summer, 4(3): 4660 .

Okonkwo, I., Ndubisi-Okolo, P. and Anagbogu. T. (2015). Challenges and Implications for Business Activities in Nigeria: A Critical Review. Journal of Policy and Development Studies, Vol. .9 (2): 157-168.

Olagunju, K., (2015). Evaluating Traffic Congestion in Developing Countries - A Case Study of Lagos of Nigeria: A Paper Presented at 2015 Chattered Institute of Logistics and Transportation (CILT). African Forum: Meru Hotels, Arusha, Tanzania.

Olanisakin, A. S. (2017). Award Night at Permanent Mission of Nigeria to the United Nations in New York, the United States of America on the 10 ${ }^{\text {th }}$ July, 2017.

Olaniyan, A. and Yahaya, A. (2016). Cows, Bandits, and Violent Conflicts: Understanding Cattle Rustling in Northern Nigeria, in: Africa Spectrum, 51, 3, 93-105.

Opera News Hubof $28^{\text {th }}$ May, 2020: Reported on Fulani militia Killings in Southern Kaduna www.operanwews.com

Piecher, H (2020). Nigeria: Unemployment Rate from 1999 t0 2019; Statista Account. www.statisca.com

Pius, U. E. (2018). Nigeria Events of 2018; the Human Right Watch; http://www.hrw.org

Sahara Reporters News: Boko Haram Killed 840 Soldiers between 2013 - 2019 www.saharareporters.com 
Sabastine, T. (2017), A Critical Review of Relevant Security Laws in Nigeria vis-à-vis Current Security Realities in West African Sub-region"; http://sebastinhon.com/aarticle-review.

Shehu, S. A., Victor E. and Binta M. (2017). The Menace of Cattle Rustling and Banditry in North-West Nigeria: A Case Study of Katsina State; IOSR Journal of Research \& Method in Education Vol.7 (6) : 40-47.

Sule R. N., (2015). Ethno-Religious Conflicts, Mass Media and National Development: The Northern Nigeria Experience; A Thesis in the Department of Religion and Philosophy, Faculty of Arts, Submitted to the School of Postgraduate Studies, University of Jos, in partial fulfilment of the requirements for the award of the degree of Doctor of Philosophy In Sociology of Religion of The University of Jos.

Tauna, Amos (2016), We Have Tamed Cattle Rustling, We Will Tame Kidnapping Northern Governors, in: Daily Post, 30 January, online: <http://dailypost.ng/2016/01/30/wehave-tamed-cattle-rustling-wewill-tackle-kidnapping-northern-governors> (20 March 2016).

Tella, S. A. (2012). Cost of Corruption on the Nigerian Economy, Lecture presented at the 2012 Independent Day Lecture organized by The Muslim Congress on October 6, at MKO Abiola International Stadium, Abeokuta, Ogun State. 2042012-nigerias-bokoharam-threat-how-the-eu-should-act-analysis.

Tokunbo, S. O. and Oladipupa, S. O. (2018). African Conflict in Contemporary Africa: The Nigerian Experience. Journal of Social Sciences, Vol. 12(2): 101-114

The Daily Trust Newspaper of $23^{\text {rd }}$ July, 2019, www.dailytrustnews.com

The Nation News Paper of $28^{\text {th }}$ September, 2019.www.thenationonline.net

United Nations Office on Drugs and Crime (2017). Data on Kidnapping. Presented at Security Workshop, Federal Road Safety Office Funtua on 12/March, 2017.

White, H. (2017). The Idea of National Security: What Use is it to Policy Makers? http://www.nsc.anu.edu/documents.

Worldmeter (2020). Elaboration of Data by UN, department of Economic and Social Affairs, Population Division, www.worldmeter.info. 